\title{
Effects of interdecadal climate variability on marine trophic interactions: rhinoceros auklets and their fish prey
}

\author{
April Hedd ${ }^{1,3, *}$, Douglas F. Bertram ${ }^{1,2,4}$, John L. Ryder ${ }^{1,5}$, Ian L. Jones ${ }^{1,6}$
}

${ }^{1}$ Simon Fraser University, Centre for Wildlife Ecology, Department of Biological Sciences, 8888 University Drive, Burnaby, British Columbia V5A 1S6, Canada

${ }^{2}$ Environment Canada, Canadian Wildlife Service, 5421 Robertson Rd. Delta, British Columbia V4K 3N2, Canada

${ }^{3}$ Present address: Cognitive and Behavioural Ecology, Departments of Psychology and Biology, Memorial University of Newfoundland, St. John's, Newfoundland A1B 3X9, Canada

${ }^{4}$ Present address: Environment Canada, Canadian Wildlife Service, c/o Institute of Ocean Sciences, 9860 West Saanich Road, PO Box 6000, Sidney, British Columbia V8L 4B2, Canada

${ }^{5}$ Present address: Environment Canada, Canadian Wildlife Service, 5421 Robertson Rd. Delta, British Columbia V4K 3N2, Canada

${ }^{6}$ Present address: Department of Biology, Memorial University of Newfoundland, St. John's, Newfoundland A1B 3X9, Canada

\begin{abstract}
This paper presents time-series information on the diet composition and breeding performance of rhinoceros auklet Cerorhinca monocerata at Triangle Island, British Columbia, Canada, during 15 breeding seasons between 1976 and 2001. Three shifts in ocean climate occurred within British Columbia during this period (1976-77, 1989-90, 1998-99), allowing us to evaluate associations between marine environmental conditions and the reproduction of this piscivorous seabird. Lipid-rich Pacific sand lance Ammodytes hexapterus was the single most important prey delivered to chicks across years (15 yr avg. 38\%; annual range 4 to $86 \%$ ). Interannual variability was high, but in general breeding performance was strongest when $0+$ sand lance predominated chick diets. Other annually important prey taxa included Pacific saury Cololabis saira, juvenile rockfishes Sebastes spp., Pacific herring Clupea pallasi and juvenile salmonid Oncorhynchus spp. The dietary importance of these prey also varied seasonally. Marine environmental conditions (evaluated using sea surface temperatures, SSTs) were clearly associated with reproduction of rhinoceros auklet, as both occurrence of sand lance in the diet and the growth rates of chicks diminished as spring SSTs increased $(\mathrm{r}=-0.680, \mathrm{p}<0.01$, and $r=-0.697, p<0.01$, respectively). We hypothesized that recruitment to local sand lance populations was temperature dependent. The strong negative relationship between dietary occurrence of $0+$ sand lance and spring SST $(\mathrm{r}=-0.560, \mathrm{p}<0.05)$, coupled with the lack of a similar relationship for 1+ sand lance ( $p>0.20)$, was consistent with the temperature-dependent recruitment hypothesis. Our data suggest that SSTs could interact with population age structure to affect the recruitment dynamics of Pacific sand lance. We estimated the annual dietary importance of $0+$ sand lance to rhinoceros auklets using spring SST and the importance of 0+ sand lance in the diet the previous year.
\end{abstract}

KEY WORDS: Ocean climate $\cdot$ Rhinoceros auklet $\cdot$ Cerorhinca monocerata $\cdot$ Forage fish $\cdot$ Ammodytes hexapterus $\cdot$ Sand lance $\cdot$ Rockfish $\cdot$ Pacific saury

Resale or republication not permitted without written consent of the publisher

\section{INTRODUCTION}

Variation in seabird breeding performance and population size has become increasingly recognized as reflective of both naturally and anthropogenically driven fluctuations in abundance of prey (Phillips et al. 1996, Anker-Nilssen et al. 1997, Davoren \& Montevecchi 2003). This is especially true when the prey are focal forage species that provide critical trophic links between zooplankton and higher-level predators. 
Relationships between prey abundance and seabird breeding performance have been well defined for systems such as the North Sea where forage fish (including lesser sandeel Ammodytes marinus and herring Clupea harengus) are commercially exploited in waters adjacent to monitored seabird populations (e.g. Monaghan et al. 1989, Phillips et al. 1996, AnkerNilssen et al. 1997). In an extreme example, where few suitable alternative prey were available, fishery-induced impacts on Norwegian herring stocks resulted in a $64 \%$ decline of Atlantic puffin Fratercula arctica populations on Røst (Anker-Nilssen et al. 1997). That study and others (Anker-Nilssen et al. 1997, Litzow et al. 2002) have also documented short-term responses of breeding seabirds to fluctuations in prey availability involving changes in chick diet, growth and survival. A recent study has suggested climactic impacts on lesser sandeel populations in the North Sea, with warm temperatures during the egg and larval stages being associated with poorer than average recruitment (Arnott \& Ruxton 2002). Understanding the underlying mechanisms is fundamental to developing predictions about possible impacts of ocean climate variation on prey stocks and the populations of upper-trophic-level predators that depend on them.

In the Northeast Pacific, El Nino Southern Oscillation (ENSO) events (every 2 to 7 yr) drive considerable interannual variability in ocean climate, while the Pacific Decadal Oscillation (PDO) characterizes fluctuations between warm- and cold-water regimes on decadal time scales (Ware 1995, Mantua et al. 1997, Hollowed et al. 2001). Ocean climate shifts associated with PDOs occurred within the Northeast Pacific in 1976-77 and in 1989-90 (Hare \& Mantua 2000, McFarlane et al. 2000), and recent evidence suggests that another shift occurred in 1998-99 (McFarlane et al. 2000, Mackas et al. 2004). Sea surface temperatures (SSTs) off the south coast of British Columbia have generally increased since the 1970s and peaked in the mid to late1990s, reaching some of the highest temperatures recorded in the 20th century. SSTs dropped abruptly and significantly in 1999, coincident with the latest shift in ocean climate.

In the California current ecosystem an $80 \%$ decline in zooplankton biomass was recorded between 1951 and 1993 (Roemmich \& McGowan 1995), coincident with both population declines for breeding planktivorous seabirds (Ainley et al. 1994, Bertram et al. 2000) and declines in birds at sea (Veit et al. 1996). Off the coast of British Columbia, nutrient levels in surface waters dropped precipitously during the warm period in the 1990s (Whitney et al. 1998). In both nearshore and offshore environments of British Columbia, the timing of peak zooplankton biomass advanced by 6 to 8 wk between 1975 and 1998 (Mackas et al. 1998) and was associated with reproductive failure for the planktivorous Cassin's auklet Ptychoramphus aleuticus due to a mismatch in the timing of reproduction and prey availability (Bertram et al. 2001). Productivity and marine survival of salmonids in British Columbia, Washington, Oregon and California were greatly reduced from the mid to late 1990s (Beamish et al. 2000, Cole 2000, Welch et al. 2000, Botsford \& Lawrence 2002, Mueter et al. 2002). Coincident with the strong La Nina event in 1999, zooplankton biomass increased and the community composition changed within coastal regions of British Columbia (Mackas et al. 2001, Mackas \& Galbraith 2002, Zamon \& Welch 2005). In 1999, the reproductive performance of both planktivorous (Cassin's auklet) and piscivorous seabirds (rhinoceros auklet Cerorhinca monocerata and tufted puffin Fratercula cirrhata) on Triangle Island, the largest seabird colony in western Canada, improved dramatically compared to previous years in the 1990s (Bertram et al. 2001; Hedd et al. 2002; Gjerdrum et al. 2003). The trend toward improved breeding performance for these species continued through 2001.

The diet and breeding performance of the rhinoceros auklet at Triangle Island, British Columbia, was quantified in the 1970s (Vermeer \& Cullen 1979, Vermeer 1980, Vermeer \& Westrheim 1984), the 1980s (Bertram \& Kaiser 1993) and the 1990s (Bertram et al. 2001), but the time-series have never been collated and analysed together. In this paper, we examine data from 15 breeding seasons spanning 1976-2001 to explore relationships between chick diet, breeding performance and ocean climate variation using SST as a proxy. Based upon Bertram et al. (2001) and Gjerdrum et al. (2003) we anticipated strong SST breeding performance associations and explored a number of hypotheses to explain associations between SST and availability of Pacific sand lance Ammodytes hexapterus, the predominant prey of breeding rhinoceros auklets at Triangle Island. Understanding the underlying mechanisms would allow us to predict the likely consequences of future ocean climate variation for rhinoceros auklet and other populations of upper-trophiclevel predators which also depend on sand lance.

\section{MATERIALS AND METHODS}

Species and study site. In 15 breeding seasons between 1976 and 2001, we examined chick diet and breeding performance of the rhinoceros auklet at Triangle Island (Fig. 1; 50 $52^{\prime} \mathrm{N}, 1^{\circ} 9^{\circ} 05^{\prime} \mathrm{W}$; hereafter Triangle). Rhinoceros auklets are medium-sized $(520 \mathrm{~g})$ alcids that provision chicks mainly with fish over 45 to $65 \mathrm{~d}$, after which time chicks fledge at 30 to $80 \%$ of adult body mass (Vermeer \& Cullen 1979, this study). 


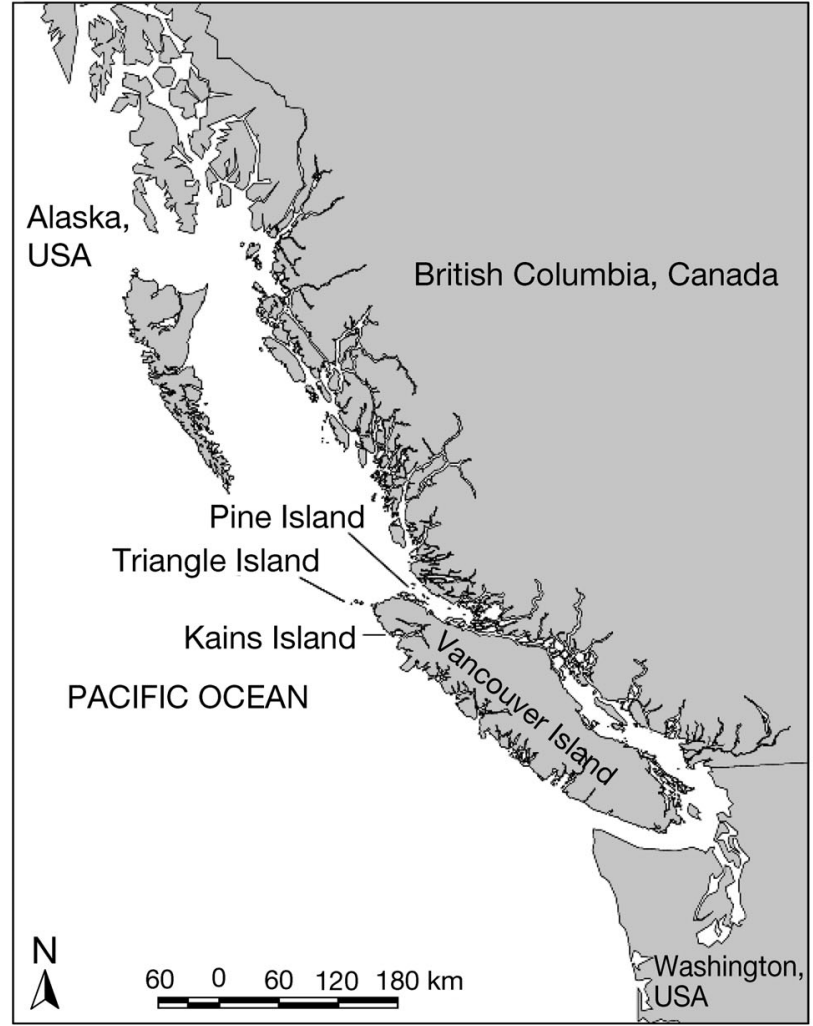

Fig 1. Map of British Columbia coast, showing location of Triangle, Pine, and Kains Islands

Adult birds can dive to $60 \mathrm{~m}$ (Burger et al. 1993, Kato et al. 2003, Kuroki et al. 2003), but those from local populations spend much of their time at sea within the upper $10 \mathrm{~m}$ of the water column (Burger et al. 1993). The foraging range of breeding rhinoceros auklets at Triangle is ca. $60 \mathrm{~km}$ (McFarlane Tranquilla et al. 2005). Adults arrive at the colony at night to provision chicks carrying multiple prey items crosswise in their bills (termed 'bill loads'). In 1989, the rhinoceros auklet population on Triangle was the second largest within Canada, estimated at 41,682 breeding pairs (Rodway 1991).

Physical oceanography: SST at Pine Island. Mean monthly SSTs at Pine Island $\left(50^{\circ} 58^{\prime} \mathrm{N}, 127^{\circ} 41^{\prime} \mathrm{W}\right.$; Fig. 1), $94 \mathrm{~km}$ east of Triangle, were used to characterize physical oceanographic conditions within the area (Institute of Ocean Sciences Lighthouse Data Web site: http://www-sci.pac.dfo-mpo.gc.ca/osap/ data/SearchTools/Searchlighthouse_e.htm; accessed 29 August 2005). Across the time-series of oceanographic information available (1937-2001), SSTs at Pine Island (April) strongly positively correlated with April values of the Pacific Decadal Oscillation (http://jisao.washington. edu/pdo/PDO. latest, accessed 29 August, 2005; r = $+0.784, \mathrm{n}=66, \mathrm{p}<0.001$ ), indicating that local SSTs are reflective of general SST variations within the Northeast Pacific ocean. Near Pine Island deep tidal mixing provides surface temperatures representative of those found throughout the water column. We extracted and averaged Pine Island SSTs across periods relevant either to the bird breeding season (April, when breeding is initiated, or May-August, which represents the entire breeding period) or to Pacific sand lance, the most important prey species at Triangle (JanuaryMarch, which represents the larval/early juvenile stage, Field 1988).

Collection of nestling food samples. Prey items intended for chicks were collected from adults in July and August 1976-79 (sampling methods detailed in Vermeer \& Westrheim 1982), in July of 1984-86 (detailed in Bertram \& Kaiser 1993) and at 7 to $10 \mathrm{~d}$ intervals between June and August of 1994-2001. From 1994 to 2001, returning adults were spotlighted with a headlamp as they landed near their burrows and captured by hand or with a dipnet. Ten to 15 bill loads were collected per sampling night and placed in plastic bags for subsequent identification and measurement (i.e. weight and standard [SL] and/or fork length [FL]). Unidentified species were frozen or preserved in 10 to $15 \%$ formalin/seawater for later identification by Moira Galbraith (Institute of Ocean Sciences, Victoria, British Columbia). Bill loads were collected in areas where no other research was being conducted. Data from 1985 included 'burrow loads' (total food delivered to a burrow in an evening), and while these were used to describe species composition they were excluded from estimates of bill load size and numbers of prey per sample.

Sand lance were divided into 2 age classes following Vermeer \& Westrheim (1984); fish from 40 to $110 \mathrm{~mm}$ FL were assumed to be $0+$ (1st year) fish, while those from 111 to $180 \mathrm{~mm}$ were assumed to be $1+$ (2nd year) fish. We used forward stepwise regression to determine if the dietary occurrence of age $0+$ sand lance in year $x$ could be estimated from SST and the presumed age structure of the sand lance population in year $x-1$ (see Arnott \& Ruxton 2002). In our analyses we used the dietary importance of $0+$ sand lance in year $x-1$ as a proxy for the relative abundance of 1+ fish the following year. Age-class assignment of Pacific herring was based upon SL, using data from Quatsino Sound, west coast of Vancouver Island (J. F. Schweigert pers. comm.). Age-class assignments for other fish species were based upon literature accounts (see references in Table 1). Diets were examined largely as \% mass, but also \% number for some analyses involving prey age structure. Unless otherwise stated, percentages describe all samples collected between June and August.

Breeding performance. Rhinoceros auklet breeding performance was assessed from chick growth rate and fledging mass (age at fledging was also estimated). Hatching success and breeding propensity were not 
assessed because these measures were not available for some years and because the sampling methodology changed over time. Sampling methods for estimating chick growth from 1976-78 were described by Vermeer et al. (1979), while Bertram et al. (1991) described the methods from 1984-86. Between 1994 and 2001 occupied burrows were checked at 3 to $5 \mathrm{~d}$ intervals prelaying, after 30 to $35 \mathrm{~d}$ when an egg was discovered, and then at 3 to $5 \mathrm{~d}$ intervals until hatching. The mass $( \pm 1 \mathrm{~g})$ and flattened wingchord $( \pm 1 \mathrm{~mm})$ of chicks was measured at $10 \mathrm{~d}$ time-specific intervals in 1994 and 1995 and at age-specific intervals from 1996 to 2001 until chicks died, disappeared or fledged from the burrow. When hatch dates were unknown, nestling ages were estimated from wingchord measurements using calibration of wing length against age for a sample of known-aged chicks in 1997 (Triangle Island Research Station, unpubl. data). Wing growth can vary under different food supply conditions, but this technique allowed us to make comparisons of similar-aged chicks among years even when hatch dates were unknown. It is most reliable when conducted early in development, and in all years chicks were included only if estimated to be $\leq 25 \mathrm{~d}$ old when first measured. In 1996, chicks were measured at hatch, 10, 20, 30, 40 and $45 \mathrm{~d}$ old and then every $2 \mathrm{~d}$ to fledging. From 1997 to 2001 chicks were measured at hatch and then at 10 , 40 and $45 \mathrm{~d}$ old and every $2 \mathrm{~d}$ to fledging. Chicks were considered fledged if they were $>40 \mathrm{~d}$ old when last found in the burrow.

Annual population level estimates of chick growth $\left(\mathrm{g} \mathrm{d}^{-1}\right)$ were constructed for the linear phase of the growth cycle, defined by Bertram et al. (1991) as the period from 10 to $40 \mathrm{~d}$ of age. To increase the sample size for some years, this phase was extended here to 9 to $41 \mathrm{~d}$. Approximate linear growth trajectories for the 1970s were calculated from daily age-specific mass data collected by K. Vermeer and colleagues. Raw data were available for 1976, while estimates for 1977 and 1978 were derived from the literature. The 1977 value represents the difference in mean chick mass at ca. 30 and $49 \mathrm{~d}$ old, as chicks were only measured a few weeks prior to fledging (Vermeer \& Cullen 1979, Vermeer 1980). This was likely an underestimate as growth rates tend to decline as peak mass is approached (Vermeer \& Cullen 1979, their Figs. 2 \& 3). The difference in average fledging period and the average number of days between peak mass and fledging in 1976 and 1978 (Vermeer \& Cullen 1979, their Tables 2 \& 3) was used to assign $49 \mathrm{~d}$ as an average age at peak mass. This value was used in 1977 when no data on fledging period were available. The growth rate for 1978 represents the difference in mean chick mass at 9 and $41 \mathrm{~d}$ of age, derived from mean evening weights in Appendix 3 of Vermeer (1987).
Data for fledging mass, age and success in the 1970s are from Vermeer \& Cullen (1979).

In the 1980s and from 1994 to 2001, growth trajectories were derived from regression of mass on age for individual chicks, and the average value for the pooled data provided a single estimate each year. Information on fledging mass, age and success were not collected during the 1980s. From 1996 to 2001 fledging mass and age were calculated from the sample of chicks $\geq 40 \mathrm{~d}$ old when last present in the burrow. Because of different sampling protocols in 1994 and 1995, fledging mass and age are not directly comparable to subsequent years and are therefore not presented. Relationships between nestling diet and performance and the associations of both with SST were examined with correlational analyses. Data are presented as means $\pm 1 \mathrm{SE}$ and statistical significance was accepted at $\mathrm{p}<0.05$.

\section{RESULTS}

\section{SST and breeding phenology of rhinoceros auklets}

Spring (April) SST at Pine Island averaged $7.9 \pm$ $0.1^{\circ} \mathrm{C}$ (range 6.6 to $9.5^{\circ} \mathrm{C}$, Fig. 2A) between 1937 and 2001. At the outset of rhinoceros auklet studies at Tri-
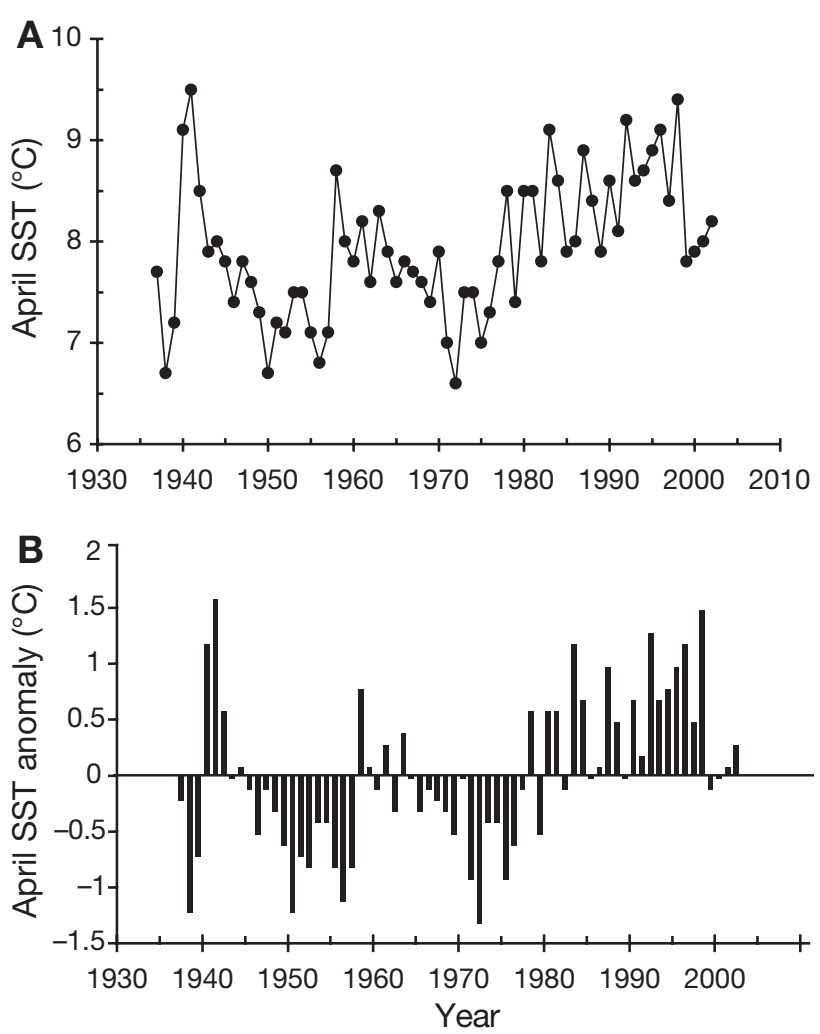

Fig. 2. (A) Mean spring (April) SST at Pine Island, British Columbia, 1937-2002 and (B) SST anomalies over same period 
angle (mid-1970s), spring SSTs were relatively cool, with 1972 being the coldest year on record. Temperatures were variable, but normal to warm in the 1980s, and they warmed substantially through the 1990s (Fig. 2B). At $9.4^{\circ} \mathrm{C}, 1998$ was the second warmest spring in the preceding $65 \mathrm{yr}$. An abrupt shift occurred in 1999 when the spring SST dropped below $8^{\circ} \mathrm{C}$. Temperatures during 2000-01 were close to the long-term average.

Concurrent with the general shift from relatively cool to warmer waters between the 1970s and 1990s, rhinoceros auklets bred significantly earlier in the season (see also Bertram et al. 2001). Mean hatch dates in the 1970s and 1980s averaged 28 June $\pm 3.4 \mathrm{~d}$ but $14 \mathrm{~d}$ earlier (14 June $\pm 0.9 \mathrm{~d})$ between 1994 and $2001\left(F_{1,12}=\right.$ 21.93, $\mathrm{p}=0.001$ ). Hatch dates during this period were negatively related to spring $\operatorname{SST}\left(F_{1,12}=6.59, \mathrm{r}=\right.$ $-0.595, \mathrm{p}=0.025)$, but, as recently demonstrated for tufted puffins at Triangle (Gjerdrum et al. 2003), hatch dates more strongly correlated with time-lagged SSTs ( 2 yr lag: $F_{1,12}=13.58, \mathrm{p}=0.003, \mathrm{r}=-0.729 ; 3 \mathrm{yr}$ lag: $F_{1,12}=7.38, \mathrm{p}=0.019, \mathrm{r}=-0.617 ; 4 \mathrm{yr}$ lag: $F_{1,12}=27.20$, $\mathrm{p}<0.000, \mathrm{r}=-0.833)$.

\section{Diet of rhinoceros auklets}

1204 food samples (total mass = $29408 \mathrm{~g}$ ) were collected between 1976 and 2001 (Appendix 1). Bill loads averaged $26.4 \pm 0.4 \mathrm{~g}$ (range $=0.7$ to $85 \mathrm{~g}, \mathrm{n}=1189$ ) and contained $6.4 \pm 0.2$ prey items (range $=1$ to $36, \mathrm{n}=$ 1191). While bill loads collected in July were largely similar in size across years, those from 1979 were significantly smaller than those from 1977, 1986, 1997 and $2001\left(F_{13,616}=3.34, \mathrm{p}<0.001\right.$, Tukey's HSD p < 0.05). Examining only the period 1994-2001 when samples were collected from June through August, bill load mass varied within years $\left(F_{2,745}=15.30, \mathrm{p}<0.001\right)$, with smaller loads delivered to chicks in June than in July or August (Tukey's HSD p < 0.001).

Fish accounted for 99\% (7849 of 7906) of all prey items and contributed more than $97 \%$ by mass to the chick diet each year. Cephalopods constituted the remainder, occurring in $3.5 \%(n=42)$ of samples. Seventeen fish taxa from 15 families were identified (Appendix 1). Five dominant taxa, in decreasing order of importance, were Pacific sand lance (mean annual mass contribution $=38 \%$, range 4 to $86 \%$ ), Pacific saury Cololabis saira (24\%, range 0 to $91 \%$ ), juvenile rockfishes Sebastes spp. (16\%, range 0 to $57 \%$ ), Pacific herring Clupea pallasi ( $7 \%$, range 0 to $45 \%$ ) and juvenile salmon Oncorhynchus spp. (6\%, range 0 to $19 \%$; see Table 1 for prey size information). Together these taxa accounted for $\geq 88 \%$ by mass in 13 of the $15 \mathrm{yr}$, but their relative importance varied substantially among years (Fig. 3). Sand lance (0+ and 1+ fish) was the single most important prey overall, and it predominated in the diet in 7 yr. First-year Pacific saury predominated in 1976 and contributed $>40 \%$ by mass in both 1977 and 2001. Largely 1st-year rockfish comprised

Table 1. Cerorhinca monocerata. Information on size and age class $(0+=1 \mathrm{st} y \mathrm{y}, 1+=2 \mathrm{nd} \mathrm{yr}, 2+=3 \mathrm{rd}$ yr $)$ of main prey species in diet of rhinoceros auklet chicks at Triangle Island, along with details of mean number of fish per bill load, mean bill load mass and approximate energy density of bill loads that contained a single species. In this study, $64 \%$ of bill loads (757 of 1189 ) contained just 1 species. The energy content of bill loads was estimated on a wet mass basis (where wet mass energy densities were calculated from water percentage as follows: dry energy density $\times(1-$ proportion of water $)$; Van Pelt et al. 1997). Caloric values of prey are from Vermeer \& Devito (1986), and \% water content of prey is from Anthony et al. (2001). Whenever possible, energy content was derived using overall species biomass in diet broken down by age class. Sample sizes are given in parentheses

\begin{tabular}{|c|c|c|c|c|c|}
\hline Prey taxa & $\begin{array}{l}\text { Fork length }(\mathrm{mm}) \\
\text { and age class }\end{array}$ & No. fish & $\begin{array}{l}\text { Bill loads } \\
\text { mass }(g)\end{array}$ & $\begin{array}{c}\text { Energy } \\
\text { content }(\mathrm{kJ})\end{array}$ & $\begin{array}{l}\text { Source } \\
\text { (Ageing) }\end{array}$ \\
\hline Sand lance & $\begin{array}{c}88 \pm 0.4(3888) \\
0+, 1+\end{array}$ & $8.6 \pm 0.4(289)$ & $24.3 \pm 0.7(289)$ & 130 & Vermeer \& Westrheim (1984) \\
\hline Pacific saury & $\begin{array}{c}167 \pm 1.7(298) \\
0+\end{array}$ & $2.0 \pm 0.1(174)$ & $34.8 \pm 0.9(174)$ & 145 & Suyama et al. (1996) \\
\hline Rockfish spp. & $\begin{array}{c}60 \pm 0.2(1871) \\
0+\end{array}$ & $7.1 \pm 0.3(139)$ & $17.6 \pm 0.7(139)$ & 79 & $\begin{array}{l}\text { Phillips (1964), Westrheim \& } \\
\text { Harling (1975) }\end{array}$ \\
\hline Pacific herring & $\begin{array}{c}129 \pm 3.1(105) \\
0+, 1+, 2+\end{array}$ & $1.4 \pm 0.1(51)$ & $34.1 \pm 1.9(51)$ & 202 & J. F. Schweigert (pers. comm.) \\
\hline Sockeye salmon & $\begin{array}{c}120 \pm 2.3(37) \\
1+\end{array}$ & - & - & & Burgner (1991) \\
\hline Salmon spp. & $121 \pm 2.0(53)$ & $1.5 \pm 0.1(33)$ & $27.5 \pm 1.7(33)$ & 152 & \\
\hline $\begin{array}{l}\text { Blue-throat } \\
\text { argentine }\end{array}$ & $99 \pm 0.4(326)$ & $5.4 \pm 0.2(53)$ & $31.8 \pm 1.0(53)$ & 181 & \\
\hline $\begin{array}{l}\text { ANOVA for } \\
\text { species differences }\end{array}$ & & $\begin{array}{c}F_{5,734}=70.16 \\
p<0.001\end{array}$ & $\begin{array}{c}F_{5,733}=44.67 \\
\mathrm{p}<0.001\end{array}$ & & \\
\hline
\end{tabular}




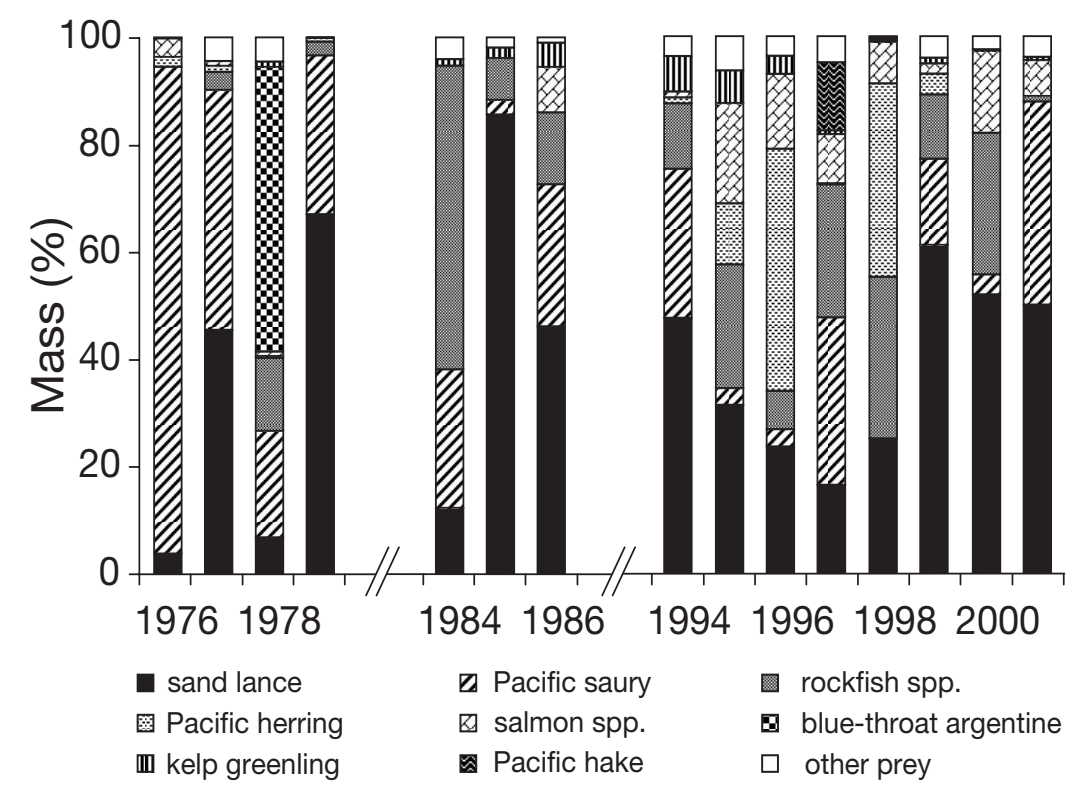

Fig. 3. Annual composition (by mass) of rhinoceros auklet nestling diet at Triangle Island, British Columbia, 1976-2001

$>20 \%$ of chick diet in the 4 yr after 1994 and were the most important prey in 1984 (Fig. 3). Pacific herring contributed significantly to the diet only in the $1990 \mathrm{~s}$, being the most important prey both in 1996 (45\% by mass; mainly 1+ fish) and 1998 (36\% by mass; mainly 0+ fish). Second-year sockeye salmon Oncorhynchus nerka constituted $\geq 5 \%$ of the chick diet from 1995 to 1998, while in 1986, 1995-96, and 2000-01 unidentified juvenile salmonids accounted for an additional 7 to $15 \%$ of the diet. Unusual within the time-series was 1978, when blue-throat argentine Nansenia candida comprised $53 \%$ of the diet. Apart from 1998 when argentine were found in 2 samples, this species did not otherwise appear in the chick diet at Triangle. Three other species made annual mass contributions greater than $4 \%$ : kelp greenling Hexagrammos decagrammus (1986, 1994 and 1995), sablefish Anoplopoma fimbria (1977 and 1978) and Pacific hake Merluccius productus (1997). The 7 remaining taxa were of minor importance.

Bill load mass differed according to the type of prey delivered (Table 1). Loads composed of Pacific saury, Pacific herring and blue-throated argentine were significantly heavier than those of sand lance or rockfish (Tukey's HSD p < 0.001). Rockfish loads were the lightest delivered to chicks, while salmon loads were intermediate. The number of prey per bill load also differed by species (Table 1), with meals of Pacific saury, Pacific herring, and salmon consisting of a few large fish, while loads of sand lance and blue-throat argentine instead contained more, smaller fish (Tukey's HSD all $\mathrm{p}<0.01)$.

\section{Breeding performance of rhinoceros auklets}

Annual growth rate anomalies (Fig. 4) indicate that while chick growth was variable between 1976 and 2001, rhinoceros auklets at Triangle experienced a succession of poor years in the 1990s. Overall, growth rates averaged $5.5 \pm$ $0.4 \mathrm{~g} \mathrm{~d}^{-1}$, with a low of $2.6 \mathrm{~g} \mathrm{~d}^{-1}$ in 1976 and a high of $9.1 \mathrm{~g} \mathrm{~d}^{-1}$ in 1985 (Table 2). Mass and age at fledging and fledging success were also highly variable among years. Mean annual fledging mass was $295 \pm 17 \mathrm{~g}$ (range 224 to $361 \mathrm{~g}$ ), and chicks fledged at an average age of $52 \pm 1$ d (range 49 to 56 d). Means of fledging mass and age were not correlated across years, but they were determined together in only $8 \mathrm{yr}$. Fledging success ranged from 34 to $97 \%$ (overall average $75 \pm 6 \%$; Table 2 ), and there was no statistically significant relationship between success and either fledging mass or age (success vs. mass, $\mathrm{r}=0.548, \mathrm{n}=9, \mathrm{p}=0.124$; success vs. age, $\mathrm{r}=$ $-0.558, \mathrm{n}=8, \mathrm{p}=0.152$ ), but sample sizes were small. Annual mean chick growth rate was strongly positively related to both fledging mass $\left(\mathrm{r}^{2}=0.712, \mathrm{n}=9, \mathrm{p}=0.004\right)$ and fledging success $\left(\mathrm{r}^{2}=0.667, \mathrm{n}=11, \mathrm{p}=0.002\right)$ but unrelated to fledging age $\left(r^{2}=0.290, n=8, p=0.169\right)$.

Strong reproductive performance of rhinoceros auklet at Triangle was dependent upon chicks receiving a diet dominated by sand lance. The annual mean growth rate of chicks and mean chick fledging success were both strongly positively related to the proportion of sand lance in the diet (Fig. 5). In this regard, 1978 was anomalous as growth was rapid when chick meals consisted largely of blue-throat argentine (Table 2). Excluding 1978, mean fledging mass was also related

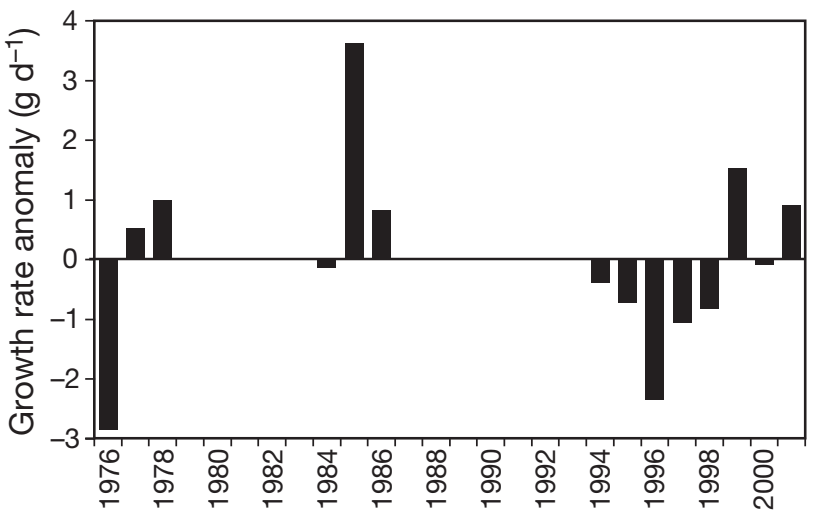

Fig. 4. Annual growth rate anomalies $\left(\mathrm{g} \mathrm{d}^{-1}\right)$ of nestling rhinoceros auklets at Triangle Island, British Columbia, 1976-2001 
Table 2. Cerorhinca monocerata. Summary of breeding performance of rhinoceros auklet at Triangle Island, British Columbia, 1976-2001. Growth rates (GR) were estimated between 9 and $41 \mathrm{~d}$ of age (see 'Materials and methods'). Sample sizes are given in parentheses, and errors are standard with the exception of fledging mass and age data from the 1970s (Vermeer \& Cullen 1979) where the authors refer to $95 \%$ confidence intervals

\begin{tabular}{|c|c|c|c|c|c|c|}
\hline Year & $\begin{array}{l}\text { Type of } \\
\text { growth study }\end{array}$ & $\begin{array}{l}\text { Growth rate } \\
\qquad\left(\mathrm{g} \mathrm{d}^{-1}\right)\end{array}$ & $\begin{array}{l}\text { Fledging } \\
\text { mass }(g)\end{array}$ & $\begin{array}{l}\text { Fledging } \\
\text { age }(d)\end{array}$ & $\begin{array}{c}\text { Fledging } \\
\text { success }(\%)\end{array}$ & Source and type of data analysed \\
\hline 1976 & Daily weighing & $2.6 \pm 0.4(25)$ & $266 \pm 20(15)$ & $56 \pm 4(9)$ & $34(44)$ & $\begin{array}{l}\text { GR calculated using raw data of } \\
\text { Vermeer \& Cullen (1979); remain- } \\
\text { der from Vermeer \& Cullen (1979) }\end{array}$ \\
\hline 1977 & Daily weighing & 6.0 & $333 \pm 16(36)$ & - & $65(62)$ & $\begin{array}{l}\text { GR derived from Vermeer \& } \\
\text { Cullen (1979) and Vermeer (1980) } \\
\text { remainder from Vermeer \& Cullen } \\
(1979)\end{array}$ \\
\hline 1978 & Daily weighing & 6.5 & $361 \pm 15(27)$ & $51 \pm 1(27)$ & $83(35)$ & $\begin{array}{l}\text { GR derived from Appendix } 3 \\
\text { Vermeer (1987); remainder from } \\
\text { Vermeer \& Cullen (1979) }\end{array}$ \\
\hline 1984 & $10 \mathrm{~d}$ interval & $5.3 \pm 0.2(47)$ & - & - & - & $\begin{array}{l}\text { GR calculated using raw data of } \\
\text { Bertram et al. (1991) }\end{array}$ \\
\hline 1985 & $10 \mathrm{~d}$ interval & $9.1 \pm 0.4(23)$ & - & - & - & $\begin{array}{l}\text { GR calculated using raw data of } \\
\text { Bertram et al. (1991) }\end{array}$ \\
\hline 1986 & $10 \mathrm{~d}$ interval & $6.3 \pm 0.4(37)$ & - & - & - & $\begin{array}{l}\text { GR calculated using raw data of } \\
\text { Bertram et al. (1991) }\end{array}$ \\
\hline 1994 & $10 \mathrm{~d}$ interval & $5.1 \pm 0.3(33)$ & - & - & $69(36)$ & This study \\
\hline 1995 & $10 \mathrm{~d}$ interval & $4.7 \pm 0.2(61)$ & - & - & $81(73)$ & This study \\
\hline 1996 & Sequential growth & $3.1 \pm 0.4(13)$ & $229 \pm 10(10)$ & $50 \pm 1(10)$ & $53(15)$ & This study \\
\hline 1997 & Sequential growth & $4.4 \pm 0.1(37)$ & $224 \pm 8(44)$ & $52 \pm 1(44)$ & $70(57)$ & This study \\
\hline 1998 & Sequential growth & $4.6 \pm 0.2(28)$ & $255 \pm 10(27)$ & $52 \pm 1(27)$ & $82(34)$ & This study \\
\hline 1999 & Sequential growth & $7.0 \pm 0.3(36)$ & $341 \pm 7(35)$ & $49 \pm 1(35)$ & $97(36)$ & This study \\
\hline 2000 & Sequential growth & $5.4 \pm 0.2(40)$ & $310 \pm 7(38)$ & $52 \pm 1$ (39) & 95 (39) & This study \\
\hline \multirow[t]{2}{*}{2001} & Sequential growth & $6.4 \pm 0.2(40)$ & $334 \pm 5(41)$ & $52 \pm 1(41)$ & $96(44)$ & This study \\
\hline & Mean $\pm \mathrm{SE}$ & $5.5 \pm 0.4$ & $295 \pm 17$ & $52 \pm 1$ & $75 \pm 6$ & \\
\hline
\end{tabular}

to the proportion of sand lance in chick diet (Fig. 5C; without 1978, $\mathrm{r}=0.845, \mathrm{p}<0.01$ ). Reproductive performance was largely independent of the other main prey types, with the exception of a negative relationship between Pacific saury and fledging success $(r=-0.616$, $\mathrm{p}=0.044, y=-0.450 x+86.420)$.

\section{Associations between spring SST, diet composition and breeding performance}

There were strong associations between spring SST and both the diet composition and breeding performance of rhinoceros auklets at Triangle. We found a significant decline in the annual proportion of sand lance in the diet and a consequent decline in chick growth rate as spring SSTs increased (Fig. 6). When spring SST at Pine Island was $\leq 8^{\circ} \mathrm{C}$, sand lance accounted for $\geq 45 \%$ of the diet and chicks grew rapidly. Excluded from this regression was the extreme outlier of 1976 , when April SST was $7.3^{\circ} \mathrm{C}$, yet sand lance accounted for just $3.7 \%$ of the diet. Fledging mass also tended to decline with increasing SST, but this relationship was not significant $\left(\mathrm{r}^{2}=0.431, \mathrm{p}=\right.$ 0.077). Fledging success and spring SSTs were unrelated $\left(\mathrm{r}^{2}=0.192, \mathrm{p}=0.205\right)$.
Regardless of the dietary measure used, the contribution of age $0+$ sand lance to rhinoceros auklet chick diet declined as spring SST increased (annual \% mass and $\%$ number, respectively: $\mathrm{r}=-0.560, \mathrm{p}=0.037 ; \mathrm{r}=$ $-0.617, \mathrm{p}=0.019$; July $\%$ mass and \% number, respectively: $\mathrm{r}=-0.621, \mathrm{p}=0.018 ; \mathrm{r}=-0.599, \mathrm{p}=0.024)$. In contrast, the contribution of age $1+$ sand lance to the diet was independent of spring SST (all p > 0.21). Also, consistent with density-dependent relationships reported for lesser sandeel (Arnott \& Ruxton 2002), we found significant negative lag-1 autocorrelations between the $\%$ number of $0+$ sand lance in the rhinoceros auklet chick diet in adjacent years (annual autocorrelation: $\mathrm{n}=-0.558, \mathrm{p}=0.003$; July autocorrelation: $\mathrm{n}=-0.390$, $\mathrm{p}=0.038$ ). This means that the $\%$ number of $0+$ sand lance in the diet was negatively related to the \% number present the year before. There were similar negative autocorrelations for diet data when expressed as $\%$ mass, but these were significant only for annual measures (autocorrelation: $\mathrm{n}=-0.399, \mathrm{p}=0.034$ ).

There were further associations between spring SSTs and the fish prey that augmented chick diet in the absence of sand lance. Pacific saury also occurred in years when spring SSTs were cool, peaking at $91 \%$ by mass in 1976, the year with both the coldest spring and overall breeding season SSTs. While spring SST 

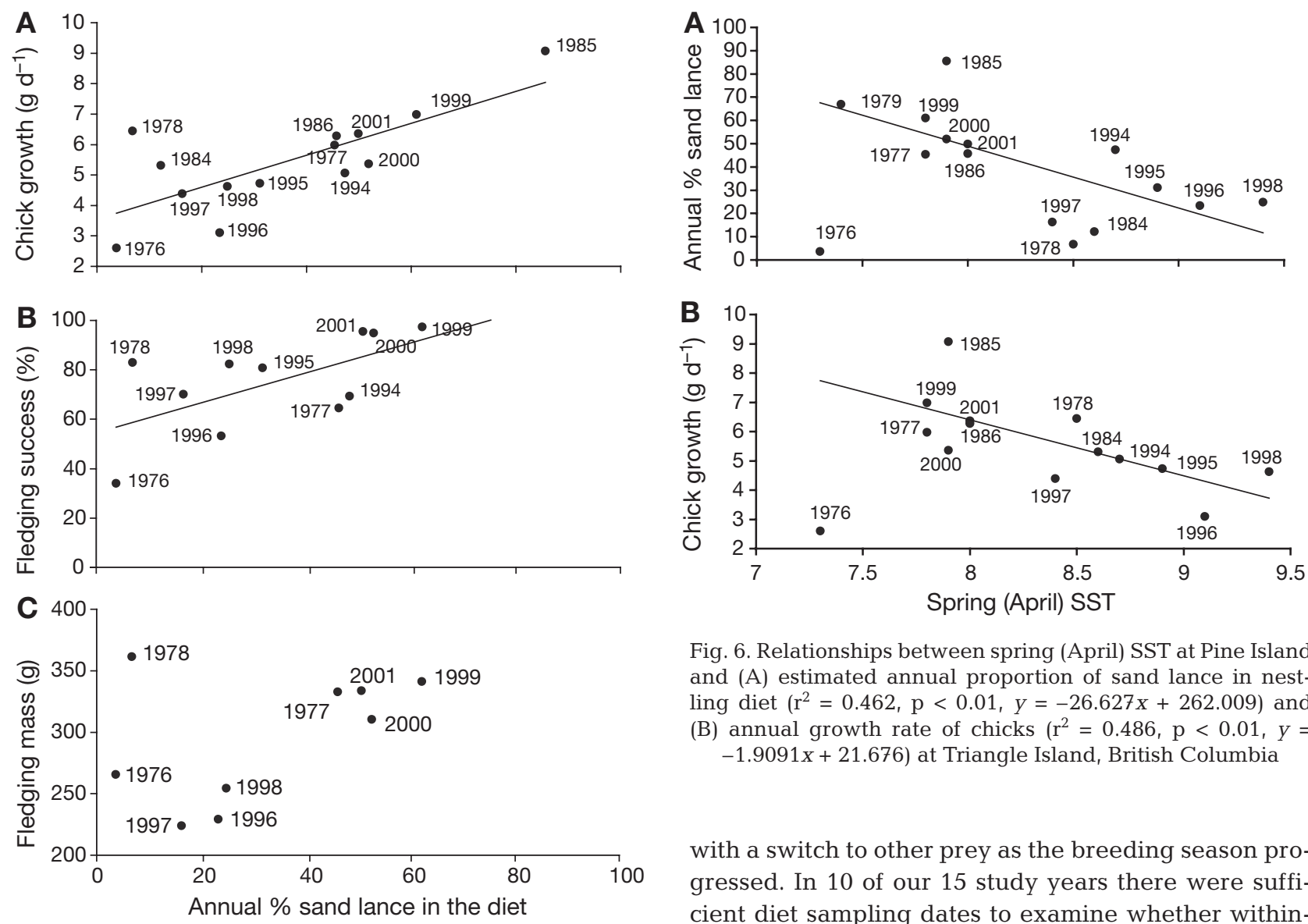

Fig. 6. Relationships between spring (April) SST at Pine Island and (A) estimated annual proportion of sand lance in nestling diet $\left(\mathrm{r}^{2}=0.462, \mathrm{p}<0.01, y=-26.627 x+262.009\right)$ and (B) annual growth rate of chicks $\left(\mathrm{r}^{2}=0.486, \mathrm{p}<0.01, y=\right.$ $-1.9091 x+21.676)$ at Triangle Island, British Columbia

Fig. 5. Relationships between annual proportion of sand lance in nestling diet and (A) mean growth rate of chicks $\left(\mathrm{r}^{2}=0.560\right.$, $\mathrm{p}<0.01, y=0.0524 \mathrm{x}+3.5578)$, (B) chick fledging success $\left(\mathrm{r}^{2}=\right.$ $0.386, \mathrm{p}<0.05, y=0.6215 x+54.584)$ and (C) chick fledging mass at Triangle Island, British Columbia

accounted for only $36 \%$ of the annual variation of Pacific saury in chick diet (Fig. 7A), this species was all but absent when spring SSTs at Pine Island exceeded $8.9^{\circ} \mathrm{C}$ (annually $<3 \%$ by mass). The dietary contribution of rockfish and herring, in contrast, tended to increase with increasing spring SST (Fig. 7B,C). Rockfish was dominant in 1984 when the spring SST was $8.6^{\circ} \mathrm{C}$. Herring formed an important part of the diet only in the 2 warmest years (1996 and 1998) when spring SSTs at Pine Island exceeded $9^{\circ} \mathrm{C}$.

\section{Associations between SST and within-season diet variation}

Along with the substantial dietary variation among years highlighted in this paper, the diet of rhinoceros auklets at Triangle also showed considerable variation within years. Broadly, these trends involved sand lance early in the season (at varying levels of dominance)

with a switch to other prey as the breeding season progressed. In 10 of our 15 study years there were sufficient diet sampling dates to examine whether withinseason variation in sand lance was associated with daily variation in SST. We used temperature data from both Pine and Kains $\left(50^{\circ} 16^{\prime} \mathrm{N}, 128^{\circ} 1^{\prime} \mathrm{W}\right)$ Islands to evaluate associations, as data from Kains Island are more representative of variation at the surface. We found limited association, with significant negative correlations for 3 yr using data from Kains Island, and for just 1 yr using data from Pine Island. Pooling across $10 \mathrm{yr}$ produced significant negative correlations between daily \% sand lance and daily SST (Kains Island: $\mathrm{r}=-0.533, \mathrm{p}<0.001$; Pine Island: $\mathrm{r}=-0.507, \mathrm{p}<0.01$ ) but with high variability. For temperatures between 14 and $14.5^{\circ} \mathrm{C}$ at Kains Island, for example, the \% sand lance in the diet ranged from 0 to $74 \%$. Variation was similarly high at Pine Island. Overall, SST accounted for 26 to $28 \%$ of the daily variation in \% sand lance in the diet.

\section{Estimating annual dietary occurrence of $0+$ sand lance}

We used forward stepwise regression to estimate the occurrence of $0+$ sand lance (SL) in rhinoceros auklet chick diet in year $x$ (by \% number and \% mass) using various measures of SST [(1) Spring (April), (2) breeding season (May-August) and (3) larval/early juvenile stage for sand lance (January-March)], along with the 

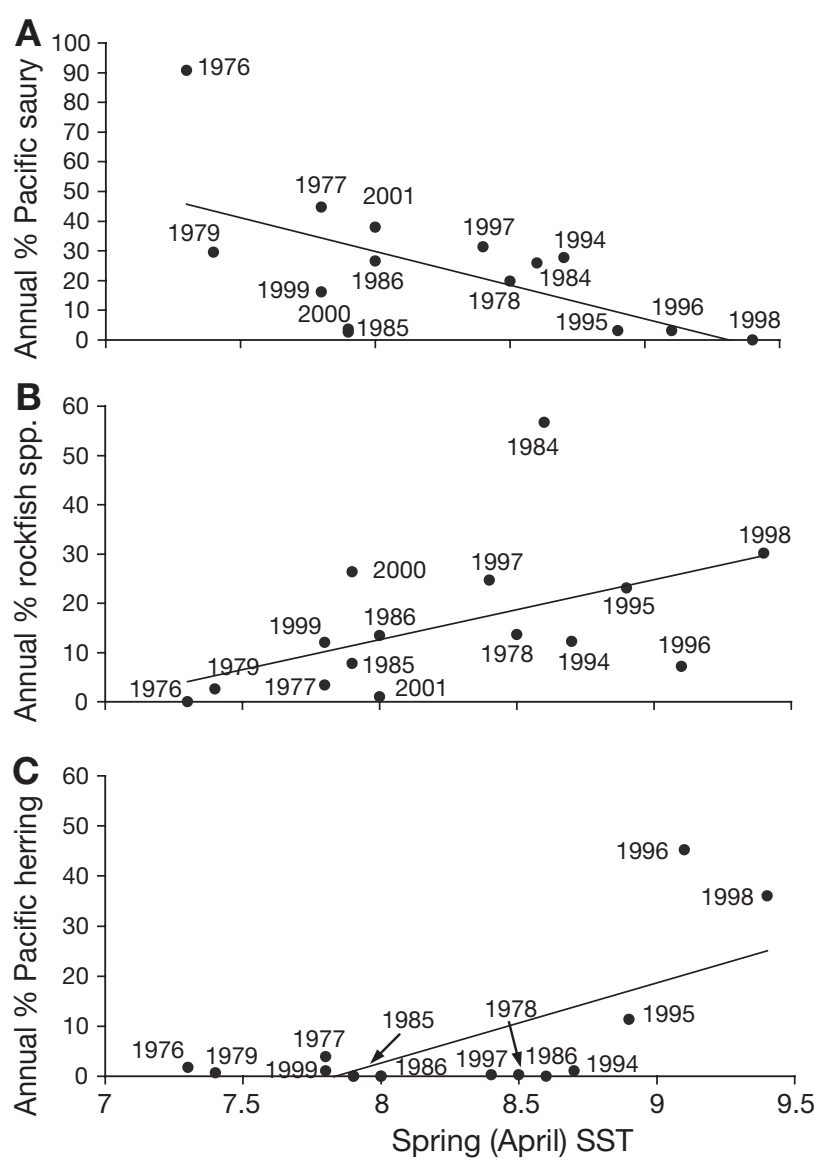

Fig. 7. Relationships between spring (April) SST at Pine Island and estimated annual proportions of (A) Pacific saury $\left(\mathrm{r}^{2}=\right.$ $0.360, \mathrm{p}=0.018, y=-22.712 x+211.500)$, (B) rockfish spp. $\left(\mathrm{r}^{2}=\right.$ $0.253, p=0.056, y=12.177 x-84.804)$ and (C) Pacific herring $\left(\mathrm{r}^{2}=0.473, \mathrm{p}<0.01, y=15.847 x-123.897\right)$ in diet of nestling rhinoceros auklets at Triangle Island, British Columbia

dietary importance of the $0+$ cohort in the previous year $(x-1)$. All percent data were arcsine transformed prior to analysis. Details of the equations follow.

Annual dietary measures:

$\arcsin \%$ number $0+\mathrm{SL}=-0.229$ (April SST)

-0.224 (breeding season SST)

$-0.727(\arcsin \%$ number $0+$ SL $x-1)+4.910$

$\mathrm{r}^{2}=0.917, \mathrm{p}<0.001$

$\arcsin \%$ mass $0+\mathrm{SL}=-0.269($ April SST)

$-0.463(\arcsin \%$ number $0+$ SL $x-1)+2.694$

$\mathrm{r}^{2}=0.628, \mathrm{p}=0.019$

July dietary measures:

$\arcsin \%$ number $0+\mathrm{SL}=-0.631$ (breeding season SST)

$-0.600(\arcsin \%$ number $0+\mathrm{SL} x-1)+6.906$

$r^{2}=0.878, p<0.001$

$\arcsin \%$ mass $0+\mathrm{SL}=-0.376$ (April SST)

$-0.373(\arcsin \%$ number $0+$ SL $x-1)+3.558$

$\mathrm{r}^{2}=0.649, \mathrm{p}=0.015$
Annual variation in dietary occurrence of $0+$ sand lance was significantly related to the dietary importance of $0+$ sand lance in year $x-1$ (suggesting density dependence in the sand lance population) and SSTs. These relationships form the basis to evaluate mechanistic linkages and to develop predictions about breeding performance of rhinoceros auklets in relation to SST variability.

\section{DISCUSSION}

This paper presents a retrospective analysis of timeseries information on the diet composition and breeding performance of a pursuit-diving piscivorous marine bird, the rhinoceros auklet, spanning 3 decades (1976-2001) and encompassing 3 shifts in ocean climate in British Columbia. SSTs during the study period were highly variable and spanned extremes in the $65 \mathrm{yr}$ temperature record. Our main findings were strong associations between SST, prey species selected for offspring provisioning and the breeding performance of rhinoceros auklets at Triangle Island, the largest and most diverse seabird breeding colony on Canada's west coast. While we do not have sufficient annual data to examine the $1976-77$ or $1989-91$ regime shifts, the annual time-series initiated in the 1990s allowed us to bound the 1997-98 ENSO and the shift in ocean climate in 1999. The abrupt change in 1999 and reported impacts on zooplankton community composition (Mackas et al. 2001) were reflected as dietary shifts and improved breeding performance in the Triangle seabird community (Bertram et al. 2001, Hedd et al. 2002, Gjerdrum et al. 2003).

Variations in SST were clearly associated with the diet composition of rhinoceros auklets, demonstrating that, when conditions were cool, sand lance (particularly 0+ age fish) dominated the diet and breeding performance was strongest. The mechanism for stronger performance with increased sand lance is uncertain, but in general seabird growth and breeding performance is enhanced when chicks are fed high lipid fish (Hunt et al. 1996, Golet et al. 2000, Takahashi et al. 2001, Litzow et al. 2002). While age $0+$ sand lance and rockfish (which is associated with poor breeding performance at Triangle) have similar energy densities (3.18 and $2.97 \mathrm{~kJ} \mathrm{~g}^{-1}$ wet mass, Van Pelt et al. 1997; 19.68 and $21.77 \mathrm{~kJ} \mathrm{~g}^{-1}$ dry mass, Vermeer \& Devito 1986), our observation of stronger performance with sand lance is consistent with the $40 \%$ increase in energy delivered per bill load (Table 1). The 40\% energy increase resulted both from larger sized meals and the higher energy density of $1+$ sand lance $(4.95 \mathrm{~kJ}$ $\mathrm{g}^{-1}$ wet mass, Van Pelt et al. 1997), as this age class comprised $43 \%$ of sand lance biomass at Triangle. 
Despite the high energy content of all other delivered prey (i.e. Pacific saury, Pacific herring and salmon; Table 1), blue-throat argentine was the only alternate species that resulted in rapid nestling development at Triangle. At the Seabirds Rocks colony, southern British Columbia, rhinoceros auklet chicks grew well when fed Pacific herring and salmon (Bertram et al. 2002), perhaps suggesting that rates of delivery of these particular prey to Triangle are lower. Prey size and timing of availability likely also contributed to the observed patterns of nestling performance. While large fish efficiently provision older nestlings, their sheer bulk can result in mortality for younger chicks, as reported for the large Pacific saury delivered to Triangle in 1976 (Vermeer 1980). In this study, meals of Pacific saury, Pacific herring and salmon contained a few, often very large fish (Table 1), while meals of species associated with strong growth (blue-throat argentine and sand lance) contained multiple, smaller fish. Whether rates of delivery of alternate prey are lower at Triangle or their size/age classes are inappropriate, few prey other than sand lance have been associated with successful reproduction for rhinoceros auklet at this site.

The favourable association between sand lance and breeding performance at Triangle, coupled with the lack of similar positive associations for other prey, suggests that, if available, rhinoceros auklets would likely choose sand lance for their chicks. Sand lance are abundant during spring and summer in shallow inshore, shelf areas in depths to $100 \mathrm{~m}$ (Reay 1970, Field 1988). They alternate between lying buried in the substrate and swimming in pelagic schools and are found in association with sandy or fine-gravel substrates (Hart 1973). Below we briefly review the habitat and temperature associations for the alternate prey species of rhinoceros auklets at Triangle and briefly discuss their reproductive implications.

\section{Prey fish species}

Although variable, Pacific saury has contributed to the chick diet of rhinoceros auklet at Triangle in many years (Fig. 3), and it has been particularly important late in the season. Juvenile Pacific saury are epipelagic and found in association with warm, offshore water masses from California to Japan (Hart 1973). Causes of the late season shift to Pacific saury are unclear but may be linked to seasonal water mass movements. Pacific saury of the size range delivered to rhinoceros auklet nestlings have been captured by surface trawl surveys in early August, west of Cape Scott off the northwest coast of Vancouver Island (Cooke et al. 1991), and well within the foraging distances of auklet parents (McFarlane Tranquilla et al. 2005). Although their within-season appearance was associated with warmer waters (as Pacific saury was generally delivered in August), we detected a negative association with spring SST. This species was virtually absent in the years when spring SSTs exceeded $8.9^{\circ} \mathrm{C}$. Perhaps similar to sand lance (see below), strong year classes were favoured when primary productivity of the ocean was high and spring SSTs were cool. The significant negative association between fledging success and importance of Pacific saury in the diet suggests it was utilized in years when prey more suitable for chick provisioning were scarce.

There was a general increase between the 1970s and early 2000s in the importance of rockfish in the diet of rhinoceros auklet at Triangle. Rockfish were a minor dietary component in the 1970s; they constituted $>50 \%$ of the diet in 1984 and have been an important dietary component (>20\%) in 4 yr since 1994. They were inconsequential at a number of other colonies along the British Columbia coast between 1995 and 1998 (Seabird Rocks and SGaang Gwaii, Queen Charlotte Islands), likely reflecting geographic variation in the species composition of local fish fauna (Bertram et al. 2002). Although we have no information on where the rockfish originated, they could have been obtained quite close to the breeding colony as waters surrounding the Scott Islands are within a Rockfish Conservation Area (Area 111, Scott Islands) protected from all rockfish harvesting by Fisheries and Oceans Canada (www.pac.dfo-mpo.gc.ca./recfish/Restricted_Areas/ Rockfish_Maps_2004/MgmtAreas2004/coordinate_ pages/049_e.htm, accessed 26 August 2005). At Triangle, consumption of rockfish occurred in warmer years and was associated with poor chick growth. Meals comprised solely of rockfish were lighter than average, a feature attributed to the body morphology of the genus (i.e. auklets had difficulty carrying many individuals of this relatively small, deep-bodied fish, Bertram et al. 2002). Depressed nestling growth was also observed for rhinoceros auklet on Pine Island in the 1980s (Bertram et al. 1991), when rockfish comprised a significant proportion of the diet (Bertram \& Kaiser 1993).

One and 2 yr old Pacific herring contributed to the chick diet at Triangle in the 1990s, particularly 1996 and 1998, 2 of the warmest and poorest reproductive years in our time-series. Similar to sand lance, juvenile herring are found over the shelf and are numerous inshore in their first year (Hourston 1958, 1959). They are important prey for many seabirds, marine mammals and fish in the region (Schweigert 1997). The increased occurrence of 2 yr old herring in rhinoceros auklet chick diet in 1996 was supported by indepen- 
dent stock assessment, as the 1994 year class was the strongest seen off the west coast of Vancouver Island in 2 decades (J. F. Schweigert pers. comm.). The increased importance of herring in years when sand lance are rare in chick diet could indicate that birds adjust their search to more coastal areas when ocean prey are scarce.

Juvenile salmon contributed more to the diet of rhinoceros auklet at Triangle in the 1990s and early 2000s (annual average 9.3\%) than they did in the $1970 \mathrm{~s}(1.8 \%)$ or $1980 \mathrm{~s}(2.8 \%)$. In summer, juvenile salmon can be found close to shore, migrating in a narrow band within $30 \mathrm{~km}$ of the coast before moving offshore to feed in the North Pacific (Hartt \& Dell 1986). Blue-throat argentine was the only alternate prey resulting in strong chick growth for rhinoceros auklets at Triangle, but it appeared in the diet only in 1978 (except for 2 meals in 1998). Blue-throat argentine is a cold-water, bathypelagic species (Hart 1973) that was apparently locally abundant in 1978. In 1978 it was a major prey of chinook Oncorhynchus tshawytscha and sockeye salmon along the northeast coast of Vancouver Island (Vermeer \& Westrheim 1984, A. Ostrom pers. comm.), when it was also found in rhinoceros auklet nestling diets at Pine Island (Vermeer \& Westrheim 1984). Like the auklets, occurrence of this species in salmon diets was unusual and had not been recorded previously.

Apart from suggesting that rhinoceros auklets would choose sand lance if available, it was unclear if exposure to different water masses resulted in the variable patterns of prey selection observed or if different oceanographic conditions resulted in variable avian search strategies. While beyond the scope of this paper, investigation of the fish species assemblages delivered to rhinoceros auklet chicks under various SST conditions may provide additional insight into ecosystem response. Clearly, strong breeding performance for the rhinoceros auklet was associated with cool SSTs. The declines in breeding performance observed with increasing SST have also been demonstrated for Cassin's auklet (Bertram et al. 2001) and tufted puffin (Gjerdrum et al. 2003) at Triangle. Bertram et al. (2001) suggested that temperature-performance relationships could be used to predict the effects of future climate change on seabird populations. Such predictions are powerful if the underlying mechanisms and processes are understood. For rhinoceros auklet, prediction involves understanding the linkages between SST and availability of their dominant prey, sand lance, near Triangle. There are no independent data on sand lance populations, but below we assess a number of hypotheses to explain how SST could influence sand lance availability to rhinoceros auklets.

\section{Temperature-related hypotheses explaining sand lance variation in chick diet}

\section{H1: Recruitment of sand lance around Triangle increases at cooler temperatures}

The strong negative relationship between spring SST and the annual importance of $0+$ sand lance in rhinoceros auklet chick diet and the lack of a similar relationship for 1+ sand lance supports the recruitmenttemperature hypothesis. The anomalous 1976 data point (low spring SST, few sand lance) led Bertram et al. (2001) to suggest that sand lance recruitment could be dome-shaped in relation to ocean temperature, as demonstrated for rock sole Lepidopsetta bilineata (Fargo \& McKinnell 1989) with poor recruitment at high and low spring SST and favourable recruitment at intermediate SSTs. A $16 \mathrm{yr}$ time-series for tufted puffins, for which sand lance is also a focal prey species at Triangle, indicates a bell-shaped curve between fledging success and breeding season SST (Gjerdrum et al. 2003), providing further support for a domeshaped recruitment function for sand lance.

Annual recruitment of Ammodytes is highly variable and associated with temperature fluctuations at other sites (Hamada 1966, Arnott \& Ruxton 2002). In the North Sea, poor recruitment has been associated with above-average ocean temperatures during the egg and larval stages (Arnott \& Ruxton 2002), an effect most pronounced near the southern end of the species' range. Hamada (1966) also demonstrated temperaturerecruitment associations for Japanese sand lance Ammodytes personatus, where increased fishery catches of $0+$ fish correlated with low water temperatures during spawning.

The superior reproductive performance of Triangle seabirds in cool years has been proposed to operate through effects on the timing of zooplankton availability, in particular Neocalanus copepods, relative to the time of seabird breeding (Bertram et al. 2001). In years when spring was early and warm, zooplankton biomass both peaked and ended early, resulting in a mismatch between predator and prey. Alternatively, in cool years the temporal availability of copepods in surface waters was extended, providing a better match with seabird requirements. Irrespective of seasonal timing, cool ocean temperatures near Triangle also reflect conditions of well-mixed nutrients and increased primary productivity of the ocean (e.g. Beamish et al. 1999). We would expect greater overall zooplankton abundance in cool-water years, favouring planktivorous seabirds directly (e.g. Jones et al. 2002). Moreover, we also see rapid nestling growth for piscivorous rhinoceros auklets (this study and Bertram et al. 2001) and tufted puffins (Gjerdrum et al. 2003) in cool years 
when diets are dominated by $0+$ sand lance. As sand lance themselves feed primarily on copepods (Field 1988), cool years would provide favourable feeding conditions for young fish and thus contribute to strong recruitment to local populations (see also Wright \& Bailey 1996). In British Columbia, Pacific sand lance are within the southern third of their range (Hart 1973), and, based upon Myers' (1998) assertion regarding environment-recruitment relationships, we expect the proposed associations between spring SST, copepod availability and sand lance recruitment to hold in this system across years.

$\mathrm{H} 2$ : Spatial distribution of sand lance is temperature dependent

Warming SSTs could induce horizontal or vertical shifts in sand lance distribution that could affect their availability to rhinoceros auklets. On the Newfoundland Grand Banks Northern sand lance Ammodytes dubius moved to deeper (cooler) waters as temperatures increased in summer (Winters 1983) and Japanese sand lance burrowed in the sand and became dormant when water temperatures exceeded $20^{\circ} \mathrm{C}$ (Nagoshi \& Sano 1979). While similar distributional shifts could plausibly explain patterns of sand lance occurrence in rhinoceros auklet diet (see Gjerdrum et al. 2003), our data did not provide strong support for this interpretation. Within the temperature range observed, there was little indication of a boundary above which sand lance became unavailable to the auklets; however, as occurrence declined with increasing temperature, it is possible that further temperature increases could have induced distributional shifts. In this study, the initial seasonal dominance of sand lance, its temporal persistence and species replacements were highly variable among years, collectively supporting the interpretation that they relate more to between- than within-season temperature fluctuations.

H3: Predation intensity on sand lance increases with increasing temperature

Almost every marine piscivore in British Columbia feeds on sand lance, and distributional shifts in response to temperature could increase the diversity and/or abundance of sand lance predators (e.g. Pacific hake, Benson et al. 2002), thereby limiting its availability to rhinoceros auklets. While changing species assemblages and competitive interactions for common prey could reduce sand lance availability to rhinoceros auklets, the lack of information on sand lance population size and the impact of all its predators make this hypothesis difficult to evaluate.
While these, and likely numerous other, hypotheses could account for observed patterns of sand lance in the rhinoceros auklet diet, we suspect that the most likely scenario relates to both temperature effects on sand lance recruitment and density-dependent population processes. Ocean temperatures influence both the abundance and temporal persistence of zooplankton in surface waters, which likely affects prey availability to and perhaps survival of $0+$ sand lance. As demonstrated for Ammodytes elsewhere (Arnott \& Ruxton 2002), 0+ sand lance off British Columbia appear to be affected by population age structure. Annual dietary occurrence of $0+$ sand lance for rhinoceros auklets could be estimated from SSTs combined with an index of $0+$ sand lance abundance the previous year. This concurs with Arnott \& Ruxton (2002), who demonstrated negative relationships between lesser sandeel recruitment and both ocean temperature and population size of $1+$ sandeels. For lesser sandeel the density-dependent effects imposed by $1+$ fish were largely responsible for alternating years of high and low recruitment. Physical disturbance of the spawning bed by burrowing adults and juveniles was suggested as a possible mechanism, as adults do not use separate spawning grounds (Reay 1970, Arnott \& Ruxton 2002). Juvenile and adult lesser sandeels may also cannibalize eggs or hatching larvae, but this explanation seems unlikely for Pacific sand lance, as Robards \& Piatt (1999) suggested it is not cannibalistic.

\section{CONCLUSIONS}

The time-series data sets assembled here for rhinoceros auklet combined with those for Cassin's auklet (Bertram et al. 2001) and tufted puffin (Gjerdrum et al. 2003) highlight how impacts of ocean climate variation on prey populations result in large interannual variation of seabird breeding performance at Triangle. Negative relationships between spring SST and chick growth were demonstrated for both rhinoceros and Cassin's auklets, and a dome-shaped relationship was found for tufted puffins, where growth was maximal at intermediate temperatures (Gjerdrum et al. 2003). For rhinoceros auklets the predictive linear SST breeding performance model (Bertram et al. 2001) likely reflects linkages between climate, ocean productivity, sand lance recruitment and their availability to breeding seabirds. Our results are consistent with both climatic and population age structure effects on sand lance and provide a basis for investigating mechanisms that underpin variation in recruitment and population size of this focal species.

Extremely poor breeding performance for all seabird species in the warmest years (1996 and 1998) suggests 
climate-trophic linkages for both piscivores and planktivores (Bertram et al. 2001, Hedd et al. 2002, Gjerdrum et al. 2003, this study). Only the tufted puffin, however, exhibited near complete breeding failure in the warmest years, suggesting a sensitivity that surpassed that of the other species. Puffins tend to be diurnal foragers that provision young multiple times per day, a strategy that restricts parental foraging range (Ostrand et al. 1998). In contrast, each rhinoceros auklet parent provisions its young at most once per night (max. 2 feeds $\mathrm{d}^{-1}$ ) and has the capacity to search for prey at broader geographic scales. Rhinoceros auklets may also feed on diel vertically migrating species such as herring that may be less available to puffins during the day.

The striking and consistently negative effects of ocean warming on the breeding performance of seabird species within the Triangle community warrant further development on the use of seabirds as indicators of climate change. Seabird time-series data provide relatively inexpensive information about the responses of upper-trophic-level predators to ocean climate variability. The relative ease with which dietary and reproductive information can be collected from seabirds, and the trophic insights gained, necessitates incorporating seabird colony studies as an integral part of any marine ecosystem monitoring program.

Acknowledgements. We are grateful to have assembled data from 3 separate investigations on Triangle. We thank K. Vermeer for his original data from the 1970s. G. W. Kaiser oversaw the field program in the mid-1980s. In 1994 the Centre for Wildlife Ecology involving Canadian Wildlife Service and Simon Fraser University began a continuous long-term seabird ecology study at Triangle. M. Hipfner currently oversees this program, and we thank him for the use of data from 2001 . We gratefully acknowledge the vast numbers of technician and volunteer field workers who collected data for this study. The Canadian Coast Guard has made the current program viable with ship and helicopter logistic support. BC Parks granted permission to work on the Anne Vallée Ecological Reserve, Triangle Island (Ecological Reserve Permit \#ST9910186). Thanks to M. Galbraith for taxonomic identification of difficult-to-identify diet items. Grants from the Vancouver Foundation (1994) I.L.J., the Nestucca Trust Fund (1998-2002) D.F.B. and G. W. Kaiser, the Canadian Climate Change Action fund to D.F.B. (Project \#A112), the Important Bird Areas Community Action Fund (IBACAF) of the Canadian Nature Federation D.F.B., and a collaborative United States National Oceanographic and Atmospheric Administration (US NOAA) grant in 1998 (NA77RJ0453) led by W. J. Sydeman are gratefully acknowledged. Additional financial support was provided by Canadian Wildlife Service, Environment Canada's Science Horizons Youth Internship Programme (A.H. and J.L.R.), the Federal Public Service Youth Internship Program (Career Edge, J.L.R.), the Centre for Wildlife Ecology at Simon Fraser University, and NSERC Operating and Equipment grants to F. Cooke.

\section{LITERATURE CITED}

Ainley DG, Sydeman WJ, Hatch SA, Wilson UW (1994) Seabird population trends along the west coast of North America: causes and extent of regional concordance. Stud Avian Biol 15:119-133

Anker-Nilssen TA, Barrett RT, Krasnov JV (1997) Long- and short-term responses of seabirds in the Norwegian and Barent Seas to changes in stocks of prey fish. In: Forage fishes in marine ecosystems. Proceedings of the International Symposium on the Role of Forage Fishes in Marine Ecosystems. Alaska Sea Grant College Program Report No. 97-01. University of Alaska, Fairbanks, AK

Anthony JA, Roby DD, Turco KR (2000) Lipid content and energy density of forage fishes from the northern Gulf of Alaska. J Exp Mar Biol Ecol 248(1):53-78

Arnott SA, Ruxton GD (2002) Sandeel recruitment in the North Sea: demographic, climatic and trophic effects. Mar Ecol Prog Ser 238:199-210

Beamish RJ, Noakes DJ, McFarlane GA, Klyashtorin L, Ivanov VV, Kurashov V (1999) The regime concept and natural trends in the production of Pacific salmon. Can J Fish Aquat Sci 56:516-526

Beamish RJ, Noakes DJ, McFarlane GA, Pinnix W, Sweeting R, King J (2000) Trends in coho marine survival in relation to the regime concept. Fish Oceanogr 9:114-119

Benson AJ, McFarlane GA, Allen SE, Dower JF (2002) Changes in Pacific hake (Merluccius productus) migration patterns and juvenile growth related to the 1989 regime shift. Can J Fish Aquat Sci 59:1969-1979

Bertram DF, Kaiser GW, Ydenberg RC (1991) Patterns in the provisioning and growth of nestling rhinoceros auklets. Auk 108:842-852

Bertram DF, Kaiser GW (1993) Rhinoceros auklet (Cerorhinca monocerata) nestling diet may gauge Pacific sand lance (Ammodytes hexapterus) recruitment. Can J Fish Aquat Sci 50:1908-1915

Bertram DF, Jones IL, Cooch E, Knetchel H, Cooke F (2000) Survival rates of Cassin's and rhinoceros auklets at Triangle Island, British Columbia. Condor 102:155-162

Bertram DF, Mackas DL, McKinnell SM (2001) The seasonal cycle revisited: interannual variation and ecosystem consequences. Prog Oceanogr 49:283-307

Bertram DF, Golumbia T, Davoren GK, Harfenist A, Brown J (2002) Short visits reveal consistent patterns of interyear and intercolony variation in seabird nestling diet and performance. Can J Zool 80:2190-2199

Botsford LW, Lawrence CA (2002) Patterns of co-variability among California Current chinook salmon, coho salmon, Dungeness crab, and physical oceanographic conditions. Prog Oceanogr 53:283-305

Burger AE, Wilson RP, Garnier D, Wilson M-PT (1993) Diving depths, diet and underwater foraging of Rhinoceros auklets in British Columbia. Can J Zool 71:2528-2540

Burgner RL (1991) Life history of the sockeye salmon (Oncorhynchus nerka). In: Groot C, Margolis L (eds) Pacific salmon life histories. University of British Columbia Press, Vancouver, p 1-118

Cole J (2000) Coastal sea surface temperature and coho production off the north-west United States. Fish Oceanogr 9: $1-16$

Cooke KD, Waddell BJ, Groot C (1991) Data record of juvenile salmonids and other fish species captured by surface trawl off coastal British Columbia in August, 1988 and September, 1990. Can Data Rep Fish Aquat Sci 837: $1-79$

Davoren GK, Montevecchi WA (2003) Signals from seabirds 
indicate changing biology of capelin stocks. Mar Ecol Prog Ser 258:253-261

Fargo J, McKinnell S (1989) Effects of temperature and stock size on year class production for rock sole (Lepidopsetta bilineata) in Northern Hecate Straight, British Columbia. In: Beamish RJ, McFarlane GA (eds) Effects of ocean variability on recruitment and an evaluation of parameters used in stock assessment models. Can Spec Publ Fish Aquat Sci 108:327-333

Field LJ (1988) Pacific sand lance, Ammodytes hexapterus, with notes on related Ammodytes species. In: Wilimovsky NJ, Incze LS, Westrheim SJ (eds) Species synopses: life histories of selected fish and shellfish of the Northeast Pacific and Bering Sea. University of Washington Press, Seattle, p 15-33

Gjerdrum C, Valleé AMJ, St. Clair CC, Bertram DF, Ryder JL, Blackburn GW (2003) Tufted puffin reproduction reveals ocean climate variability. Proc Natl Acad Sci USA 100(16): 9377-9382

Golet GH, Kuletz KJ, Roby DD, Irons DB (2000) Adult prey choice affects chick growth and reproductive success in Pigeon Guillemots. Auk 117:82-91

Hamada T (1966) Studies on fluctuation in the abundance of larval sand lance. III. Relationship to weather and sea conditions during the breeding season. Bull Jpn Soc Sci Fish 32:309-405

Hare SR, Mantua NJ (2000) Empirical evidence for North Pacific regime shifts in 1977 and 1989. Prog Oceanogr 47: 103-145

Hart JL (1973) Pacific fishes of Canada. Fish Res Board Can Bull 180

Hartt AC, Dell MB (1986) Early ocean migration and growth of juvenile Pacific salmon and steelhead trout. Int N Pac Fish Comm Bull 46:1-105

Hedd A, Ryder JL, Cowen L, Bertram DF (2002) Inter-annual variation in the diet, provisioning and growth of Cassin's auklet at Triangle Island, British Columbia: responses to variation in ocean climate. Mar Ecol Prog Ser 229:221-232

Hollowed AB, Hare SR, Wooster WS (2001) Pacific basin climate variability and patterns of Northeast Pacific marine fish production. Prog Oceanogr 49:257-282

Hourston AS (1958) Population studies on juvenile herring in Barkley Sound, British Columbia. J Fish Res Board Can 15: 909-960

Hourston AS (1959) Effects on some aspects of the environment on the distribution of juvenile herring in Barkley Sound. J Fish Res Board Can 16:283-308

Hunt GL Jr, Decker MB, Kitaysky A (1996) Fluctuations in the Bering Sea ecosystem as reflected in the reproductive ecology and diets of kittiwakes on the Pribilof Islands, 1975 to 1991. In: Greenstreet SPR, Tasker ML (eds) Aquatic predators and their prey. Fishing News Books, Oxford, p 142-153

Jones IL, Hunter FM, Robertson GJ (2002) Annual adult survival of least auklets (Aves, Alcidae) varies with largescale climatic conditions of the North Pacific Ocean. Oecologia 133(1):38-44

Kato A, Watanuki Y, Naito Y (2003) Foraging behaviour of chick-rearing rhinoceros auklets Cerorhinca monocerata at Teuri Island, Japan, determined by acceleration-depth recording micro data loggers. J Avian Biol 34:282-287

Kuroki M, Kato A, Watanuki Y, Niizuma Y, Takahashi A, Naito Y (2003) Diving behavior of an epipelagically feeding alcid, the rhinoceros auklet. Can J Zool 81:1249-1256

Litzow MA, Piatt JF, Prichard AK, Roby DD (2002) Response of pigeon guillemots to variable abundance of high-lipid and low-lipid prey. Oecologia 132:286-295
Mackas DL, Galbraith M (2002) Zooplankton community composition along the inner portion of Line P during the 1997-1998 El Niño event. Prog Oceangr 54:423-437

Mackas DL, Goldblatt R, Lewis AG (1998) Interdecadal variation in developmental timing of Neocalanus plumchrus populations at Ocean Station $\mathrm{P}$ in the subarctic North Pacific. Can J Fish Aquat Sci 55:878-1893

Mackas DL, Thompson RE, Galbraith M (2001) Changes in the zooplankton community of the British Columbia continental margin 1985-1999, and their covariation with oceanographic conditions. Can J Fish Aquat Sci 58: 685-702

Mackas DL, Peterson WT, Zamon JE (2004) Comparisons of interannual biomass of zooplankton communities along the continental margins of British Columbia and Oregon. Deep-Sea Res II 51(6-9):875-896

Mantua NJ, Hare SR, Zhang Y, Wallace JM, Francis RC (1997) A Pacific interdecadal climate oscillation with impacts on salmon production. Bull Am Meterol Soc 78:1069-1079

McFarlane GA, King JR, Beamish RJ (2000) Have there been recent changes in climate? Ask the fish. Prog Oceanogr 47:147-169

McFarlane GA, Tranquilla L, Ryder JL, Boyd WS, Shisko SG, Amey K, Bertram DF, Hipfner JM (2005) Diurnal marine distributions of radio-tagged Cassin's auklets and rhinoceros auklets breeding at Triangle Island, British Columbia. Tech Rep Ser No 423. Canadian Wildlife Service, Pacific and Yukon Region, British Columbia

Monaghan P, Uttley JD, Okill JD (1989) Terns and sandeels: seabirds as indicators of changes in marine fish populations. J Fish Biol 35 (Suppl A):339-340

Mueter FJ, Peterman RM, Pyper BJ (2002) Opposite effects of ocean temperature on survival rates of 120 stocks of Pacific salmon (Oncorhynchus spp.) in northern and southern areas. Can J Fish Aquat Sci 59:456-463

Myers RA (1998) When do environmental-recruitment correlations work? Rev Fish Biol Fish 8:285-305

Nagoshi M, Sano M (1979) Population studies of sand-eels, Ammodytes personatus, in Ise Bay. I. Growth and its relation to population density. Jpn J Ecol 29:1-10

Ostrand WD, Coyle KO, Drew GS, Maniscalco JM, Irons DB (1998) Selection of forage-fish schools by murrelets and tufted puffins in Prince William Sound, Alaska. Condor 100:286-297

Phillips B (1964) Life history studies on 10 species of rockfish (Genus Sebastodes). Calif Dep Fish Game Fish Bull 126: $1-70$

Phillips RA, Caldow RWG, Furness RW (1996) The influence of food availability on the breeding effort and reproductive success of Arctic skuas Stercorarius parasiticus. Ibis 138:410-419

Reay PJ (1970) Synopsis of biological data on North Atlantic sandeels of the genus Ammodytes (A. tobianus, A. dubius, A. americanus, and A. marinus). FAO Fish Biol Synop No 82

Robards MD, Piatt JF (1999) Biology of the Genus Ammodytes, the sand lances. In: Robards MD, Willson MF, Armstrong RH, Piatt JF (eds) Sand lance: a review of biology and predator relations and annotated bibliography. Res Pap PNW-RP-521. US Department of Agriculture, Forest Service, Pacific Northwest Research Station, Portland, OR

Rodway MS (1991) Status and conservation of breeding seabirds in British Columbia. ICBP Tech Pub 11:43-102

Roemmich D, McGowan J (1995) Climate warming and the decline of zooplankton in the California Current. Science 267:1324-1326

Schweigert JF (1997) Role of Pacific herring in the British 
Columbia marine ecosystem. In: Forage fishes in marine ecosystems. Proceedings of the International Symposium on the Role of Forage Fishes in Marine Ecosystems. Alaska Sea Grant College Program Report No. 97-01. University of Alaska, Fairbanks, AK

Suyama S, Sakurai Y, Shimazaki K (1996) Age and growth of Pacific saury Cololabis saira (Brevoort) in the western North Pacific Ocean estimated from daily otolith growth increments. Fish Sci 62(1):1-7

Takahashi A, Kuroki M, Niizuma Y, Kato A, Saitoh S, Watanuki Y (2001) Importance of Japanese anchovy (Engraulis japonicus) to breeding rhinoceros auklets (Cerorhinca monocerata) on Teuri Island, Sea of Japan. Mar Biol 139: 361-371

Van Pelt T, Piatt JF, Lance BK, Roby DD (1997) Proximate composition and energy density of some North Pacific forage fishes. Comp Biochem Physiol 118A:1393-1398

Veit RR, Pyle P, McGowan JA (1996) Ocean warming and long-term change in pelagic bird abundance within the California Current system. Mar Ecol Prog Ser 139:11-18

Vermeer K (1980) The importance of timing and type of prey to reproductive success of rhinoceros auklets Cerorhinca monocerata. Ibis 122:343-350

Vermeer K (1987) Growth and nestling periods of Cassin's auklets: adaptations for planktivorous auklets to breeding at northern latitudes. Can Tech Rep Hydrogr Ocean Sci No. 93

Vermeer K, Cullen L (1979) Growth of rhinoceros auklets and tufted puffins, Triangle Island, British Columbia. Ardea 67:22-27

Vermeer K, Devito K (1986) Size, caloric content, and association of prey fishes in meals of nestling rhinoceros auklets. Murrelet 67:1-9
Vermeer K, Westrheim SJ (1984) Fish changes in diets of nestling rhinoceros auklets and their implications. In: Nettleship D, Sanger GA, Springer PF (eds) Marine birds: their feeding ecology and commercial fisheries relationships. Proceedings of the Pacific Seabird Group Symposium, Seattle, Washington. Canadian Wildlife Service Special Publications, p 96-105

Vermeer K, Cullen L, Porter M (1979) A provisional explanation of the reproductive failure of tufted puffins Lunda cirrhata on Triangle Island, British Columbia. Ibis 121:348-354

Ware DM (1995) A century and a half of change in the climate of the NE Pacific. Fish Oceanogr 4:267-277

Welch DW, Ward BR, Smith BD, Eveson JP (2000) Temporal and spatial responses of British Columbia steelhead (Oncorhynchus mykiss) populations to ocean climate shifts. Fish Oceanogr 9:17-32

Westrheim SJ, Harling WR (1975) Age-length relationships for 26 scorpaenids in the northeast Pacific Ocean. Fish Res Board Can Tech Rep 565

Whitney FA, Wong CS, Boyd PW (1998) Interannual variability in nitrate supply to surface waters of the Northeast Pacific Ocean. Mar Ecol Prog Ser 170:15-23

Winters GH (1983) Analysis of the biological and demographic parameters of northern sand lance, Ammodytes dubius, from the Newfoundland Grand Bank. Can J Fish Aquat Sci 40:409-419

Wright PJ, Bailey MC (1996) Timing of hatching in Ammodytes marinus from Shetland waters and its significance to early growth and survivorship. Mar Biol 126:143-152

Zamon JE, Welch DW (2005) Rapid shift in zooplankton community composition on the northeast Pacific Shelf during the 1998-99 El Nino-La Nina event. Can J Fish Aquat Sci 62(1):133-144 


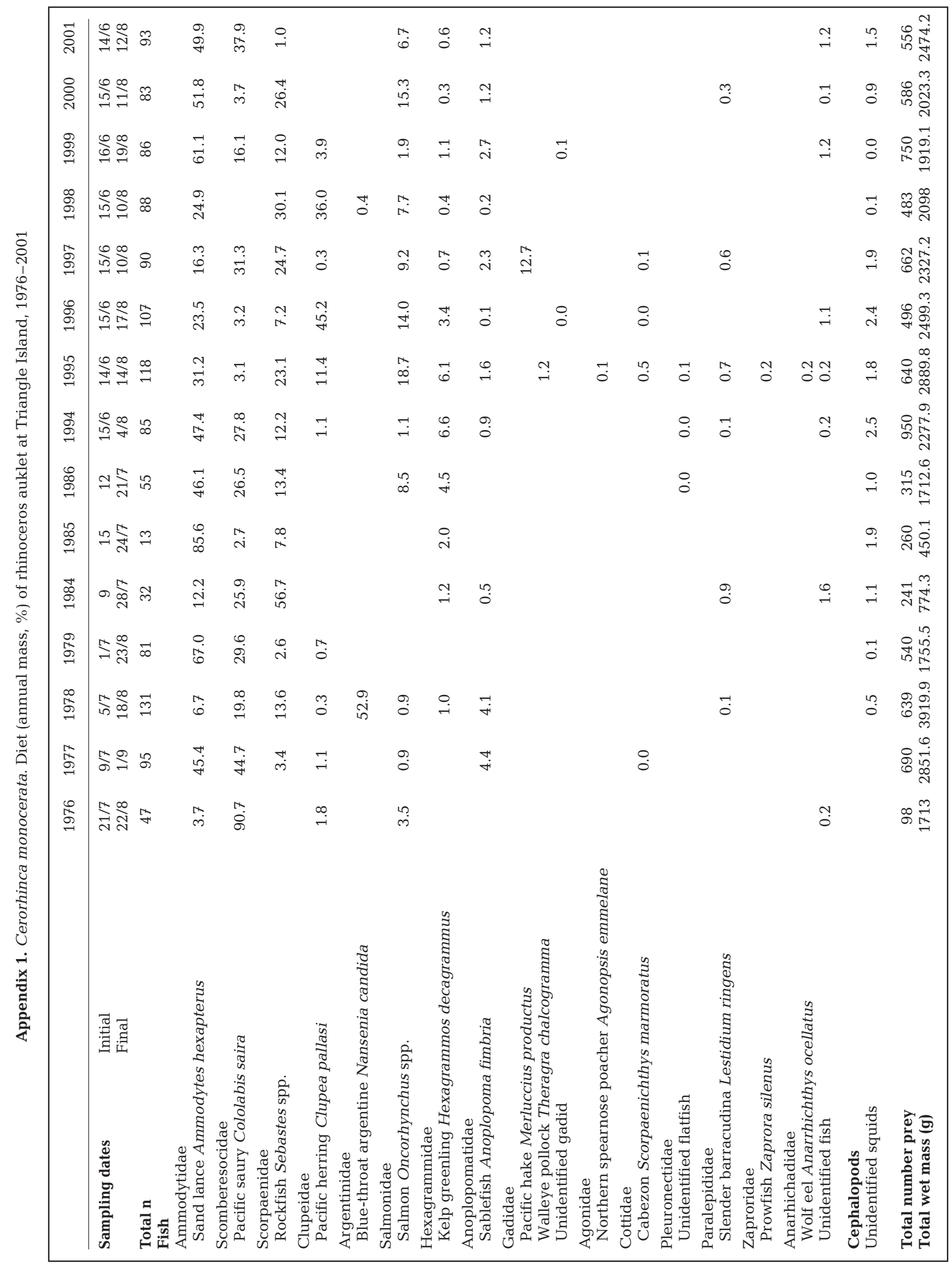

